\title{
ANALISIS PERLAKUAN AKUNTANSI UNTUK KREDIT BERMASALAH PADA PT. BANK RAKYAT INDONESIA (PERSERO) TBK CABANG MANADO
}

\author{
Deisy M. Tumbel ${ }^{1}$, Lintje Kalangi ${ }^{2}$, Stanley Kho Walandouw ${ }^{3}$ \\ ${ }^{1,2,3}$ Fakultas Ekonomi dan Bisnis, Jurusan Akuntansi, Universitas Sam Ratulangi, Jl. Kampus Bahu, Manado, \\ 95115, Indonesia \\ E-mail : tumbeldeisy@yahoo.co.id
}

\begin{abstract}
Non-performing Loans in generally are loans that pay for their mortgage payments and/or the interest has passed 90 days or the due date, or loans whose payments are timely are in doubt. Non-performing Loans consist of loans sich as substandartd, doubtfull, loss. The research method used is descriptive method, namely data collected, analyzed, and compared then drawn to conclusion. The result of the study obtained showed that the accounting treatment of non-performing loans at PT. Bank Rakyat Indonesia (persero) Tbk Manado Branch, is in accordance with SFAS No. 50, 55 and 60 concerning to the presentation, recognition, measurement and disclosure.
\end{abstract}

Keywords: Non-performing Loans, Accounting Treatment.

\section{PENDAHULUAN}

Indonesia adalah suatu Negara berkembang yang diikuti oleh berkembangnya perekomuniannnya. Peningkatan perekomunian Indonesia diikuti dengan meningkatnya kebutuhan masyarakat, dalam sistem perekomunian peran perbankan sangat penting dan strategis. Perbankan dikenal sebagai tempat meminjam uang (kredit), selain itu juga menerima simpanan giro, tabungan, dan deposito. Bank melakukan perdagangan jasa tidak melakukan perdagangan secara fisik (Hilimi, 2015). Bank mendapatkan pendapatan terbesar dari bunga, imbalan, atau pembagian hasil usaha atas kredit yang disalurkan. Bank juga harus mampu mengelolah dana dari masyarakat sebaik mungkin. Jika suatu bank tidak mampu menyalurkan kredit, sementara dana yang dimiliki bank tersebut dalam jumlah yang besar, maka bank akan mengalami kerugian karena harus membayar bunga atas simpanan.

Kredit bermasalah membuat dampak kurang baik dan dirasakan oleh negara, masyarakat, perbankan, yang ada di Indonesia. Resiko yang timbul dari kredit bermasalah yaitu tidak adanya pengembalian atau pembayaran kembali kredit yag salurkan, baik sebagian atau seluruhnya. Kredit bermasalah (Nonperforming Loan) menjadi masalah utama yang dihadapi perbankan. Ini mulai menjadi fokus sejak perekomunian Indonesia mengalami krisis global, nilai tukar rupiah yang melemah terhadap mata uang dollar AS yang mempengaruhi permintaan kredit, pelemahan rupiahpun akan mempengaruhi pada debitur bank untuk membayar cicilan, angsuran bunga, atau pokoknya dan mengakibatkan kredit bermasalah meningkat. Meningkatnya kredit bermasalah dalam jumlah yang cukup besar, mengharuskan perbankan untuk lebih hati-hati dalam pemberian kredit dan harus memperkokoh manajemen kreditnya. PT. Bank Rakyat Indonesia sebagai bank milik pemerintah dimana akte pendirian maupun modal dimiliki oleh pemerintah Indonesia. Sebagai bank yang sudah lama beroperasi, tentunya bank tersebut memiliki banyak metode dalam perlakuan akuntansi yang diterapkan. Kredit menjadi salah satu faktor penting dalam keberhasilan suatu bank, dimana PT. Bank Rakyat Indonesia dari tahun 2015, tahun 2016, dan tahun 2017 total kreditnya mengalami peningkatan, dari total kredit yang disalurkan tersebut tidak menutup kemungkinanan adanya pinjaman kredit yang bermasalah yang menjadi persoalan penting bagi perbankan. 
2

TINJAUAN PUSTAKA

Konsep Akuntansi. Akuntansi adalah suatu sistem yang mencatat, menggolongkan, meringkas, dan menyajikan secara sistematis transaksi-transaksi keuangan suatu badan usaha atau perusahaan, kemudian menasfirkan hasilnya (Priyati, 2013). Akuntansi merupakan sistem informasi yang menyediakan laporan keuangan untuk pihak-pihak yang berkepentingan tentang kegiatan ekonomi dan kondisi suatu perusahaan. (Warren et al, 2017:6).

Akuntansi Keuangan. Akuntansi Keuangan adalah bagian dari akuntansi yang menyediakan informasi ekonomi dan informasi keuangan kepada investor, kreditor, dan pengguna eksternal lainnya (Weygant et al, 2015 : 6). Akuntansi keuangan menjadi bidang akuntansi yang menyediakan informasi akuntansi secara umum bagi pemakai informasi dan membatu pengambilan keputusan pihak diluar organisasi (Pontoh, 2013:2).

Pernyataan Standar Akuntansi Keuangan. Menurut Standar Akuntansi Keuangan, Ikatan Akuntansi Indonesia (2004:6), pegertian Standar Akuntansi Keuangan yaitu standart yang menjadi acuan untuk mengetahui metode dan kebijakan yang seragam, dalam penyajian informasi keuangan yang berbeda, sehingga mampu dilakukan perbandingan dengan mudah, tentang konsep, metode yang digunakan, prosedur, kebijakan, kebiasaan, dan praktek yang bisa diterima secara umum.

Konsep Pengakuan dan Pengukuran Unsur Laporan keuangan menurut Standar Akuntansi Keuangan. Menurut Standar Akuntansi Keuangan, Ikatan Akuntan Indonesia (2007:4), konsep laporan keuangan terdiri dari : (1) Pengakuan Unsur-Unsur Laporan Keuangan; (2) PSAK No. 50 tentang Penyajian Instrumen Keuangan; (3) PSAK No. 55 tentang Pengakuan dan Pengukuran Instrumen Keuangan; (4) PSAK No. 60 tentang Pengungkapan Instrumen Keuangan.

Konsep Kredit. Pengertian kredit menurut Peraturan Perundang-undangan No. 10 tahun 1998, tentang perbankan dan booklet perbankan Indonesia 2010, yaitu: menyediakan uang, dan memiliki ketentuan sesuai perjanjian yang disetujui, dan disepakati oleh kedua pihak pinjam meminjam, dan mengharuskan pihak peminjam melunasi utangnya tersebut dalam jangka waktu tertentu dengan pemberian bunga.

Pengertian Kredit Bermasalah. Lata (2014), menyatakan bahwa kredit bermasalah mengacu pada aset keuangan suatu bank yang tidak lagi menerima pembayaran bunga atau angsuran sesuai waktu yang ditetapkan. Konsumen tidak lagi memenuhi kewajiban untuk membayar angsuran setiap bulannya, membuat kredit tersebut menunggak sampai diakui sebagai kredit macet (Talumewo, 2018). Dalam pemberian kredit, akan muncul piutang usaha yang menjadi aktiva lancar dan bagian dari modal kerja perusahaan, dengan begitu adanya resiko yang harus ditanggung perusahaanpun semakin besar, dimana bisa saja terjadi kredit macet dan menurunkan performa perusahaan (Kaunang, 2017). Kondisi saat kredit yang telah disalurkan kepada masyarakat atau debitur tidak mendapatkan pembayaran kembali pada waktu perjanjian, yang terdiri dari pokok berserta bunganya digolongkan menjadi Nonperforming Loan atau kredit bermasalah (Rotti, 2017).

Pengertian Bank. Bank sesuai definisi Peraturan Perundang-undangan No. 10 tahun 1998, merupakan sebuah badan usaha yang tugasnya untuk menampung simpanan dana dari masyarakat dan menyalurkan kembali kepada masyarakat dalam bentuk kredit atau bentuk lainnya sesuai jangka taraf hidup masyarakat.

\section{METODE PENELITIAN}

Jenis Penelitian. Dalam penelitian ini, jenis penelitian yang digunakan adalah penelitian deskriptif kualitatif. 
Tempat, Waktu Peneltian. Penelitian ini berlokasi di PT. Bank Rakyat Indonesia (Persero) Tbk Cabang Manado, Kabupaten Minahasa Selatan, Provinsi Sulawesi utara. Waktu penelitian dimulai pada bulan Juli 2018 sampai dengan bulan Agustus 2018.

\section{Jenis, Sumber, dan Metode Pengumpulan Data Jenis Data \\ 1. Data Kualitatif \\ 2. Data Kuantitatif}

Sumber Data. Penelitian ini menggunakan sumber data yaitu data primer. Adapun yang menjadi sumber data dalam penelitian ini adalah melalui wawancara dan dokumentasi pada PT. Bank Rakyat Indonesia (persero), Tbk Cabang Manado.

\section{Metode Pengumpulan data}

1. Wawancara. Penelitian ini dilakukan dengan wawancara kepada karyawan PT. Bank Rakyat Indonesia. Metode wawancara dilakukan dengan staf bagian Kredit, kepala bagian pemasaran, dan bagian Pelaporan yag ada pada PT. Bank Rakyat Indonesia sebagai interviewee untuk memperoleh data kualitatif yang dibutuhkan.

2. Dokumentasi. Dokumentasi dilakukan dengan mengumpulkan dokumen-dokumen yang diperlukan dalam proses penelitian pada objek penelitian PT. Bank Rakyat Indonesia (persero) Tbk. Cabang Manado seperti:

a. Laporan Keuangan didalmnya laporan neraca PT. Bank Rakyat Indonesia (persero) Tbk Cabang Manado Sulut tahun 2015-2017.

b. Laporan aktivitas kredit dalam hal ini laporan pinjaman harian PT. Bank Rakyat Indonesia (persero) Tbk Cabang Manado Sulut tahun 2015-2017.

\section{Metode dan Proses analisis}

1. Tahap pertama, mengumpulkan data dari PT. BRI Cabang Manado yang dimana ini merupakan langkah awal untuk mengetahui keadaan objek terutama bagaimana ketentuan-ketentuan yang ada pada PT. Bank BRI Cabang Manado.

2. Tahap kedua, peneliti membandingkan hasil yang diperoleh dari objek penelitian dengan pernyataan standar akuntansi keuangan apakah sudah sesuai atau tidak.

3. Tahap ketiga, peneliti menarik kesimpulan dari pembahasan dan perbandingan yang telah dilakukan pada tahap sebelumnya.

4. Tahap akhir yang dilakukan yaitu dengan memberikan saran jika ditemukan adanya kekurangan yang ditemukan pada PT. Bank BRI Cabang Manado.

\section{HASIL PENELITIAN DAN PEMBAHASAN}

\subsection{Hasil Penelitian}

Penyajian Perlakuan Akuntansi untuk Kredit Bermasalah. PT. BRI Cabang

Manado, menyajikan piutang dalam aset lancar dikategorikan sebagai pinjaman atau kredit yang diberikan. PT. BRI dalam penyajian nilai piutang disajikan dalam laporan posisi keuangan atau laporan neraca, yang terlebih dahulu dikurangi dengan Penyisihan Penghapusan Aktiva Produktif (PPAP) atau Cadangan Kerugian Penurunan Nilai (CKPN). Adanya aset keuangan yang dialihkan kepada pihak ketiga, tetapi tidak memenuhi syarat pengehentian pengakuan aset, disajikan dalam neraca sebagai aset yag dijaminkan dan pihak penerima memiliki hak untuk menjual atau melakukan pengembalian.

Pengakuan Kredit Bermasalah. Tabel 1 menunujukan bahwa kategori golongan kredit berdasarkan angsuran bulanan kredit pada PT. Bank Rakyat Indonesia Cabang Manado, terbagi menjadi 5 (lima) golongan. 
Table 1. Kategori Golongan Kredit berdasarkan tunggakan bulanan

\begin{tabular}{lll}
\hline GOLONGAN & LAMA TUNGGAKAN ANGSURAN & \multicolumn{1}{c}{ KATEGORI } \\
\hline Golongan 1 & 0 hari & Kategori Lancar \\
Golongan 2 & 1-90 hari & Dalam perhatian khusus (DPK) \\
Golongan 3 & $91-180$ hari & Kurang lancar \\
Golongan 4 & 180-270 hari & Diragukan \\
Golongan 5 & Lebih dari 270 hari & Kredit macet
\end{tabular}

Sumber penelitian : PT. BRI (Persero) Tbk Cabang Manado, 2018

Golongan 1, disebut kredit lancar yaitu kredit yang tidak memiliki tunggakan. Disebut lancar apabila debitur dapat membayar pinjaman pokok dan bunga pada waktu tanggal jatuh tempo atau sebelum. Golongan yang ke-2, yaitu golongan kredit dalam perhatian khusus (DPK) yaitu golongan kredit yang memiliki tunggakan angsuran, pinjaman penuh, atau pembayaran bunga, yang tunggakannny dari tanggal jatuh tempo sampai dengan 90 hari kalender, tidak membayar. Golongan 3, yaitu kurang lancar dimana kategori ini akibat debitur tidak melakukan pmbayaran angsuran pokok, atau bunga antara 90 hari sampai 180 hari setelah tanggal jatuh tempo. Golongan 4, yaitu kredit yang diragukan terjadi apabila debitur tidak membayar angsuran pinjaman pokok dan bunganya, dimulai dari 181 hari sampai 270 hari. Golongan ke-5, disebut kredit macet yaitu kategori kredit yang debitunya tidak melakukan pembayaran berangsur-angsur setelah 270 hari dari tanggal jatuh tempo atau lebih dari 270 hari. Pengakuan kredit bermasalah (Non-performing Loan) dimulai pada kategori kredit golongan 3 sampai dengan golongan 5 atau seterusnya dimana kredit menunggak lebih dari 91 hari sampai 270 hari. Untuk kategori kredit mulai dari golongan 1 dan golongan 2, disebut sebagai Performing Loan. Adanya perubahan kolektibilitas kredit membuat kualitas kredit dan golongan kredit terjadi perubahan.

Pengukuran Kredit Bermasalah (Non-performing Loan). Dari hasil wawancara kepada PT. Bank Rakyat Indonesia Cabang Manado, menyatakan bahwa sejak 1 januari 2017, pengukuran adanya kredit bermasalah menggunakan metode cadangan penurunan nilai. Metode ini terkait bagaimana bank menentukan aset atau piutang dari pemberian kredit tidak dapat ditagih, karena bank menemukan bukti objektif adanya suatu atau lebih peristiwa yang merugikan saat pengakuan awal aset, dan dampaknya terhadap estimasi arus kas masa depan. Metode ini digunakan untuk menentukan estimasi aset keuangan secara handal dan terkontrol.

Pengungkapan Kredit Bermasalah (Non-performing Loan). Dari hasil wawancara, pengungkapan kredit bermasalah PT. BRI cabang Manado, dari metode dan kebijakan akuntansinya diuangkapkan dalam catatan atas laporan keuangan (CALK). PT. Bank Rakyat Indonesia cabang Manado, telah menggunakan sistem pencatatan menggunakan komputer untuk mempermudah dan melancarkan setiap pencatatan dan pelaporan keuangan pada akhir periode.

\subsection{Pembahasan}

Penyajian Kredit Bermasalah (Non-performing Loan) PT. BRI cabang Manado, perbandingannya dengan PSAK No. 50 (Revisi 2010). PT. BRI Cabang Manado mencatat jumlah kredit bermasalah dengan nama 'Kredit Yang Diberikan' dalam laporan neraca perusahaan sebagai bagian dari Aset, dan dikurangi dengan penyisihan pengahapusan aktiva produktif (PPAP) karena penyajian akun kredit yang diberikan merupakan bagian dari akun piutang. Cadangan kerugian piutang periode 2015-2017 PT. Bank BRI menyajikan akun piutang dengan nama akun Kredit Bermasalah dan dikurangi dengan akun cadangan kerugian piutang (CKPN) setiap angka disajikan dalam bentuk minus (-) yang artinya akan mengurangi akun kredit bermasalah. Sehingga dapat diketahui total Penyisihan Pengahapusan 
Aktiva Produktif (PPAP) PSAK 50 atau Cadangan Kerugian Penurunan Nilai (CKPN) PSAK 55 (revisi 2011). Hasil ini menunjukan bahwa PT. Bank BRI Cabang Manado sudah menerapkan PSAK No. 50 tentang Penyajian kredit bermasalah yaitu disajikan dalam komponen aktiva sebagai aset yang dijaminkan, nama akun kredit yang diberikan dimana saldonya sudah dikurangi cadangan kerugian penurunan nilai atau CKPN.

Pengakuan Kredit Bermasalah PT. BRI Cabang Manado, perbandingannya dengan PSAK No. 55 (Revisi 2011). PT. BRI Cabang Manado mengakui kredit bermasalah pada kategori angsuran menunggak yang dimulai dari Golongan ke-3 sampai Golongan ke-5, dimana tunggakan angsuran lebih dari 90 hari. Kategori golongan ke-3 yaitu kredit kurang lancar, apabila bank menemukan debitur tidak membayar angsuran pokok atau bunganya antara 90 hari sampai dengan 180 hari. Golongan ke-4 yaitu kredit yang diragukan, apabila bank menemukan tidak dilakukannya pembayaran angsuran pokok atau bunga oleh debitur, dari 181 hari sampai 270 hari. Dan Golongan ke-5 yaitu kredit macet, dimana bank menemukan debitur tidak mampu membayar secara berturut-turut, angsuran pokok atau bunganya setelah 270 hari. Untuk golongan 1 dan golongan 2 diakui sebagai Per-forming Loan. PT. Bank BRI Cabang Manado sudah menerapkan PSAK No. 55 tentang Pengakuan kredit bermasalah yaitu lebih dari 91 hari harus diakui sebagai Kredit Bermasalah.

Pengukuran Kredit Bermasalah PT.BRI Cabang Manado, perbandingannya dengan PSAK No. 55 (Revisi 2011). Kredit bermasalah PT. BRI Cabang Manado, pengukuran kredit bermasalah menggunakan metode penurunan nilai, yang merupakan sebuah kondisi dimana bank menemukan bukti adanya satu atau lebih perisiwa merugikan setelah pengakuan awal aset atau diakui sebagai piutang yang berdampak pada estimasi arus kas masa depan. Adanya kolektibilitas pembayarn kredit membuat terjadinya perubahan kualitas kredit dan golongan kredit. Metode ini berfungsi untuk mengelolah estimasi aset keuangan secara handal dan terkontrol. Dalm metode ini kelompok aset dan liabilitas diukur pada nilai wajarnya pada laporan laba rugi, tujuannya untuk diperdagangkan, dijual, atau dibeli kembali dalam waktu dekat sehingga memperoleh laba jangka pendek. Hasil ini menunjukan bahwa PT. Bank BRI Cabang Manado sudah menerapkan PSAK No. 55 tentang Pengukuran kredit bermasalah dimana PT. BRI Cabang Manado mengakui setiap peristiwa yang berpengaruh pada arus kas masa mendatang dan menggunakan konsep penurunan nilai, hanya saja nama rekening yang digunakan yaitu Penyisihan Penghapusan Aktiva Produktif(PPAP) belum menyesuaikan dengan PSAK 55 dengan nama rekening Cadangan Kerugian Penurunan Nilai (CKPN).

Pengungkapan Kredit Bermasalah PT. Bank Rakyat Indonesia (persero) Tbk. Cabang Manado dibandingkan dengan PSAK Nomor 60 (Revisi 2011). PT. Bank Rakyat Indonesia Cabang Manado telah melakukan pembagian kategori aset keuangan dan liabilitas, dengan nilai yang tercatat diungkapkan dalam laporan posisi keuagan. Nilai kredit bermasalah, pengungkapannya dalam kredit yang diberikan. Pengungkapan lainnya juga yaitu agunan, penyisiha kerugian kredit, instrumen keuangan derivatif, yang nilainya diakui dalam laporan posisi keuangan atau neraca pada nilai wajar dan dikurangi cadangan kerugian penurunan nilai. Pengungkapan kredit bermasalah (NPL) sesuai PSAK No. 60 mewajibkan PT. BRI cabang Manado menggungkapkan kredit bermasalah pada komponen akun kredit yang diberikan, dan harus menggungkapkan metode dan kebijakan akuntansi yang digunakan saat pengakuan dan pengukuran kredit bermasalah kemudian dicantumkan dalam catatan atas laporan keuangan. PT. Bank BRI Cabang Manado sudah menerapkan PSAK No. 60 tentang Pengungkapan kredit bermasalah dalam laporan keuangan sebagai Kredit yang diberikan sesuai dengan jenis, mata uang, kolektibilitas, dan sektor ekonomi untuk tujuan diadakannnya evaluasi. Ditambah dengan pengungkapan metode dan kebijakan pada Catatan Atas Laporan Keuangan (CALK). 


\section{KESIMPULAN DAN SARAN}

\subsection{Kesimpulan}

Dari hasil penelitian ini dapat ditarik kesimpulan sebagai berikut :

1. Penyajian kredit bermasalah (NPL) PT. BRI Cabang Manado, sudah sesuai dengan PSAK No. 50 ( Revisi 2010), yang mengatur Penyajian Intrumen Keuangan, dimana akun Kredit yang Diberikan disajikan dan dikurangi dengan Cadangan Kerugian Penurunan Nilai. Hanya saja pada PT. Bank Rakyat Indoensia (persero) Tbk Cabang Manado, Cadangan Kerugian Penurunan Nilai masi menggunakan nama akun Penyisihan Pengahapusan Aktiva Produktif (PPAP).

2. Pengakuan dan Pengukuran kredit bermasalah pada PT. BRI Cabang Manado, sudah sesuai dengan PSAK No. 55 (Revisi 2011), yang mengatur tentang Pengakuan dan Pengukuran Intrumen Keuangan.

3. Pengungkapan kredit bermasalah dalam laporan keuangan pada PT. BRI Cabang Manado, sudah sesuai penerapannnyan dengan PSAK No. 60 (Revisi 2011) yang mengatur Pengungkapan Intrumen Keuangan.

\subsection{Saran}

1. Penerapan Perlakuan Akuntansi untuk Kredit Bermasalah sesuai PSAK No. 50 (Reivi 2010) yang mengatur Penyajian Intrumen Keuangan, dan PSAK No.55 (Revisi 2011) yang mengatur Pengakuan dan Pengukuran Intrumen Keuangan, serta PSAK No. 60 (Revisi 2011) yang mengatur Pengungkapan Instrumen keuangan, diharapakan terus konsisten diterapkan.

2. Dalam penyajian Kredit Bermasalah pada komponen Aset sebagai nama akun Kredit yang Diberikan, sebaiknya PT. Bank Rakyat Indonesia (persero) Tbk cabang Manado, mengganti nama akun Penyisihan Pengahapusan Aktiva Produktif (PPAP) menjadi akun Cadangan Kerugian Penurunan Nilai (CKPN) seperti dalam aturan PSAK No. 55 (Revisi 2011).

\section{DAFTAR PUSTAKA}

Hilimi, Kurniawati. 2015. Analisis Penerapan PSAK No. 55 atas cadangan kerugian Penurunan Nilai Pada PT. Bank Sulut Manado. Skripsi. Universitas Sam Ratulangi. Manado.

Ikatan Akuntansi Indonesia. 2004. Standart Akuntansi Keuangan. Penerbit: Salemba Empat. Jakarta

Ikatan Akuntansi Indonesia. 2007. Penyajian Laporan Keuangan. Penerbit: $\quad$ Salemba Empat. Jakarta.

Kaunang, J., H. Sabijono, A. Wungkar. 2017. Analisis Sistem Pemberian Kredit Program Kemitraan Bina Lingkungan di PT. Jasa Raharja Persero Sulut. Jurnal Riset Akuntansi Going Concern (12. 2 (2017):605-613).

Lata, Rabeya S. 2014. Non-Performing Loan and Its Impact on Profitability of State Owned Commercial Banks in Bangladesh: An Empirical Study. International Journal. Northem University. Bangladesh.

Peraturan Perundang-undangan, no. 10 Tahun 1998 Tentang Perbankan dan Booklet Perbankan Indonesia. 2010.

Pontoh, Winston. 2013. Akuntansi Konsep dan Aplikasi. Penerbit: PT. Indeks. Jakarta. Priyati, Novi. 2013. Pengantar Akuntansi. Penerbit: PT. Indeks. Jakarta.

Rotti, M., H. Manossoh, M. Kalalo. 2017. Evaluasi Pengendalian Internal Terhadap Kredit Diragukan pada PT. Bank Sulut Go di Minahasa Induk. Jurnal Riset Akuntansi Going Concern (12.2 (2017):818-827). 
Talumewo, W., G. Nangoi, V. Tirayoh. 2018. Analisis atas Penerapan Sistem Pengendalian Manajemen Pemberian Kredit pada PT. Suzuki Finance Indonesia Cabang Manado. Jurnal Riset Akuntansi Going Concern (13.2 （2018):610-619).

Weygant, J.J., P.D. Kimmel, dan D.E. Kieso. 2015. Financial Accounting IFRS Edition. 3rd ed. Wiley. USA

Warren, C. S., J.M. Reeve, dan J. Duchac. 2017. Financial Accounting. 15th ed. Cengage Learning. USA. 